JIKAP PGSD: Jurnal Ilmiah Ilmu Kependidikan

Vol,3. No,1. Tahun 2019

e-ISSN: 2597-4440 dan p-ISSN: 2597-4424

This work is licensed under a Creative Commons Attribution

4.0 International License

\title{
Meningkatkan Kemampuan Guru Melalui Pemberdayaan MGMP Sekolah di Madrasah Aliyah Negeri 1 Barru
}

\author{
Ahmad \\ Madrasah Aliyah Negeri 1 Barru, Kab. Barru \\ Email:
}

\begin{abstract}
Abstrak: Penelitian ini bertujuan untuk mengetahui peningkatan kemampuan guru melalui MGMP sekolah. Metode penelitian tindakan sekolah (PTS) dengan dua siklus yang masing-masing siklus terdiri dari tahap (1) perencanaan, (2) pelaksanaan tindakan perbaikan, (3) observasi, dan (4) refleksi. Penelitian ini melibatkan 13 orang guru mata pelajaran Matematika dan IPA sebagai subjek penelitian. Hasil penelitian menunjukkan bahwa (a) terjadi peningkatan kemampuan guru Madrasah Aliyah Negeri melalui MGMP sekolah. Hal ini dapat dilihat dari hasil observasi pada dua siklus, juga pada hasil tes yang dilakukan, terlihat peningkatan hasil tes postes secara signifikan. Pada sebaran angket yang dilakukan untuk mengetahui persepsi/pendapat guru tentang MGMP sekolah, hasil angket berada pada nilai $85 \%$, dengan demikian guru merasakan manfaat langsung dari MGMP sekolah untuk meningkatkan kemampuan mereka. Berdasarkan hasil penelitian ini penulis merekomendasikan kepada guru peserta MGMP sekolah: (1) Memanfaatkan kegiatan MGMP sekolah sebagai wadah pemberdayaan untuk meng "Up date" kemampuan profesionalnya dan (2) Memanfaatkan MGMP sekolah untuk menjalin silaturahim dan pengembangan ilmu pengetahuan.
\end{abstract}

Kata Kunci: Kemampuan Guru; MGMP Sekolah

\begin{abstract}
This study aims to determine the increase in teacher capacity through the school MGMP. School action research method (PTS) with two cycles in which each cycle consists of stages (1) planning, (2) implementation of corrective actions, (3) observation, and (4) reflection. This study involved 13 Mathematics and Natural Sciences teachers as research subjects. The results of the study showed that (a) there was an increase in the ability of teachers of State Madrasah Aliyah through school MGMP. This can be seen from the results of observations in two cycles, also in the results of the tests conducted, it was seen that the increase in posttest test results was significantly. In the distribution of questionnaires conducted to determine teacher perceptions / opinions about school MGMP, the questionnaire results were at $85 \%$, so the teacher benefited directly from MGMP schools to improve their abilities. Based on the results of this study the authors recommend to MGMP school participants teachers: (1) Utilizing school MGMP activities as a forum for empowerment to "Up date" their professional abilities and (2) Utilizing MGMP schools to establish friendship and development of knowledge.
\end{abstract}

Keywords: Teacher Ability; School MGMP 


\section{PENDAHULUAN}

Guru dalam peraturan pemerintah Nomor 74 tahun 2008 adalah pendidik profesional dengan tugas utama mendidik, mengajar, membimbing, mengarahkan, melatih, menilai, dan mengevaluasi peserta didik pada pendidikan anak usia dini jalur pendidikan formal, pendidikan dasar, dan pendidikan menengah. Kehidupan profesionalitas guru telah dituangkan dalam tiga aturan besar yang menjadi dasar sikap guru baik sebagai pribadi maupun sebagai masyarakat.

Dalam melaksanakan tugas mengajar, guru diharuskan, atau dituntut untuk memberikan yang terbaik untuk peserta didiknya. Mengajar dengan baik, dimulai dari persiapan yang matang, guru saat ini telah mengalami banyak metamorfosis (perubahan) dibandinngkan era sebelumnya. Guru sejak ia menjadi guru telah diatur dalam undang-undang yang mengikatnya untuk selalu bertindaj, bersikap, secara profesional. Pun saat ini guru harus banyak mengikutii perkembangan dan kemajuan teknologi yang semakin maju dan pesat, meninggalkan guru yang tidak memiliki sikap adaptif terhadap perkembangan zaman.

Salah satu wadah yang dapat memacu tingkat kemampuan guru adalah melalui MGMP. MGMP adalah musyawarah guru mata pelajaran yang sejenis, yang bertujuan mengaktifkan anggotanya untuk meng "up date" kemampuan mereka dalam bidang pelajarang masing-masing.

Tujuan diselenggarakannya MGMP ialah: Pertama, untuk memotivasi guru guna meningkatkan kemampuan dan keterampilan dalam merencanakan, melaksanakan, dan membuat evaluasi program pembelajaran dalam rangka meningkatkan keyakinan diri sebagai guru profesional; Kedua, untuk menyatakan kemampuan dan kemahiran guru dalam melaksanakan pembelajaran sehingga dapat menunjang usaha peningkatan dan pemerataan mutu pendidikan; Ketiga, untuk mendiskusikan permasalahan yang dihadapi dan dialami oleh guru dalam melaksanakan tugas sehari-hari dan mencari solusi alternatif pemecahannya sesuai dengan karakteristik mata pelajaran masingmasing, guru, kondisi sekolah, dan lingkungannya; Keempat, untuk membantu guru memperoleh informasi teknis edukatif yang berkaitan dengan kegiatan ilmu pengetahuan dan teknologi, kegiatan kurikulum, metodologi, dan sistem pengujian yang sesuai dengan mata pelajaran yang bersangkutan; Kelima, saling berbagi informasi dan pengalaman dari hasil lokakarya, simposium, seminar, diklat, classroom action research, referensi, dan lainlain kegiatan profesional yang dibahas bersamasama; Keenam, mampu menjabarkan dan merumuskan agenda reformasi sekolah (school reform), khususnya focus classroom reform, sehingga berproses pada reorientasi pembelajaran yang efektif.

Selain itu, MGMP pun dituntut untuk berperan sebagai : Pertama, reformator, dalam classroom reform, terutama dalam reorientasi pembelajaran efektif; Kedua, mediator, dalam pengembangan dan peningkatan kompetensi guru, terutama dalam pengembangan kurikulum dan sistem pengujian; Ketiga, supporting agency, dalam inovasi manajemen kelas dan manajemen sekolah; Keempat, collaborator, terhadap unit terkait dan organisasi profesi yang relevan; Kelima, evaluator dan developer school reform dalam konteks MPMBS; dan Terakhir, clinical dan academic supervisor, dengan pendekatan penilaian.

MGMP memiliki banyak keuntungan bagi guru, misalnya guru dapat bertukar ide, tentang masalah yang dihadapi di kelas, atau mecari informasi baru tentang dunia pendidikan secara umum dan mata pelajaran yang diampunya secara khusus.

Melihat fungsi MGMP yang sangat penting bagi guru, maka kepala sekolah sebagai manajerial dapat menjadikan MGMP sebagai pusat pembinaan guru di sekolah. Mengaktifkan MGMP di sekolah dapat menjadi momentum khusus untuk mengembangkan keprofesionalan guru yang akan berimplikasi terhadap positif terhadap sekolah.

Agar tujuan peningkatan kualitas itu tercapai maka peneliti berusaha memaksimalkan seluruh guru di Madrasah Aliyah Negeri atau disingkat MAN 1 Barru agar dapat mengikuti kegiatan MGMP sekolah. Namun, dengan jumlah guru yang banyak maka berdasarkan hasil diskusi dengan guru dan pengawas, maka MGMP sekolah akan dibagi menjadi MGMP untuk guru Matematika dan IPA, juga MGMP untuk guru IPS dan Bahasa, dan MGMP guru Agama. Pada penelitian ini yang akan diteliti adalah MGMP guru Matematika dan IPA.

Untuk tujuan tersebut, maka penulis mencoba menyusun karya tulis berupa PTS (Penelitian Tindakan Sekolah) di sekolah tempat penulis sebagai kepala sekolah, dengan tujuan meningkatkan kulitas guru di Madrasah Aliyah Negeri 1 Barru lewat pengaktifan MGMP guru Matematika dan IPA sekolah. 


\section{METODE PENELITIAN}

Penelitian ini merupakan penelitian tindakan sekolah. Pada penelitian tindakan ini menggunakan bentuk kepala sekolah sebagai peneliti. Tujuan utama dari penelitian tindakan ini adalah untuk melihat peningkatan kemampuan guru mata pelajaran melalui keterlibatannya dalam MGMP sekolah, penelitian mulai dari perencanaan, tindakan, pengamatan, dan refleksi.

Dalam penelitian ini peneliti tidak bekerjasama dengan siapapun, kehadiran peneliti sebagai kepala sekolah, pada saat MGMP, melakukan penilaian langsung kepada guru dengan membuat instrumen-instrumen yang sesuai dengan jenis penelitian

Penelitian ini bertempat di MAN 1 Barru. Sedangkan, Waktu penelitian ini dilaksanakan pada bulan September 2018 pada semester ganjil 2018/2019. Subjek penelitian adalah guru MAN 1 Barru yang berjumlah 13 guru mata pelajaran Matematika dan IPA.

Penelitian ini menggunakan Penelitian Tindakan Sekolah (PTS). Sesuai dengan jenis penelitian yang dipilih, yaitu penelitian tindakan, maka penelitian ini menggunakan model penelitian tindakan dari Kemmis dan Taggart (dalam Sugiarti, 1997: 6), yaitu berbentuk spiral dari siklus yang satu ke siklus yang berikutnya. Setiap siklus meliputi planning (rencana), action (tindakan), observation (pengamatan), dan reflection (refleksi).

Teknik pengumpulan data yang digunakan pada penelitian, yaitu observasi, studi documenter, wawancara (diskusi), dan angket.

Data yang berbentuk angket akan dianalisis dengan teknik persentase, sementara data wawancara, observasi akan dideskrisikan secara kualitatif.

Indikator kinerja yang dipakai sebagai

indikator keberhasilan dalam penelitian ini adalah:

a. Guru terlibat aktif menggunakan MGMP sebagai wadah diskusi.

b. Guru dapat menjelaskan manfaat MGMP sekolah.

c. Guru dapat menyusun dokumen K.13 dengan baik dan sesuai standar pelaksanaan.

d. Guru dapat merumuskan Penilaian berbasis HOTS.

e. Guru memahami materi PKG dan PKB

\section{HASIL DAN PEMBAHASAN}

Penelitian ini menggunakan instrumen tes dan nontes, sebelum memasuki siklus I, peneliti melakukan observasi awal dengan menggunakan instrumen tes sebagai pretes, dan wawancara pada 13 guru matematika dan IPA yang menjadi responden penelitian.

Hasil penelitian dari setiap siklus akan dipaparkan sebagai berikut:

\section{Hasil pratindakan}

Pada tes awal pratindakan, peneliti membagikan guru, instrumen yang akan dipakai sebagai pretes kegiatan MGMP yang akan berlangsung selama 4 kali pertemuan.

Instrumen tersebut memuat kisi-kisi pertanyaan sebagai berikut:

a. Penguasaan metode-metode pembelajaran

b. Penguasaan filsafat pendidikan

c. Penguasaan pendidikan karakter bangsa

d. Penguasaan materi PKG dan PKB. berikut ini:

Hasil tes dapat dilihat pada tabulasi

Tabel 2. Hasil pratindakan (pretes)

\begin{tabular}{cccc}
\hline No. & Kualifikasi & $\begin{array}{c}\text { Jumlah } \\
\text { guru }\end{array}$ & $\begin{array}{c}\text { Persentase } \\
(\boldsymbol{\%})\end{array}$ \\
\hline $\mathbf{1}$ & Sangat Baik & 0 & 0 \\
\hline $\mathbf{2 .}$ & Baik & 4 & 31 \\
\hline 3. & Cukup & 8 & 62 \\
\hline 4. & Kurang & 1 & 8 \\
\hline & Jumlah & 13 & 100 \\
\hline
\end{tabular}

Pada tabel 2. dapat dilihat bahwa guru yang berada pada hasil tes (pretes) sangat baik tidak ada, dengan kualifikasi baik 4 orang atau $31 \%$, kualifikasi cukup 8 orang atau $62 \%$, dan satu orang atau $8 \%$ berkualifikasi kurang.

Berdasarkan hasil pratindakan di atas, maka peneliti akan melanjutkan pada dua siklus yang direncanakan.

\section{Siklus I}

a. Perencanaan

Pada perencanaa peneliti mengadakan kegiatan sebagai berikut:

1) Persiapan MGMP sekolah, membentuk kepanitiaan

2) Menyiapkan instrumen, soal dan kisi-kisi

3) Menyiapkan pedoman observasi

4) Mendiskusikan persiapan MGMP pada pengawas 


\section{b. Pelaksanaan}

Pada tahap pelaksanaan akan dibagi menjadi dua kali pertemuan untuk siklus I, dengan kegiatan sebagai berikut:

1) Pertemuan pertama tanggal 08 September 2018 dan 15 September 2018 dengan materi wawasan pendidikan, metode-metode pembelajaran, simulasi beberapa metode, dan pembuatan soal-soal berbasis HOTS.
2) Observasi dilakukan secara langsung oleh peneliti dengan pedoman observasi yang telah dibuat sebelumnya.

c. Observasi

Hasil pengamatan untuk pertemuan pertama pada siklus I dapat dilihat pada tabulasi berikut ini:

Tabel 3. Hasil observasi pertemuan I dan II siklus I

\begin{tabular}{rlcc}
\hline No & \multicolumn{1}{c}{ Item pengamatan } & Jumlah & Persentase \\
\hline $\mathbf{1}$ & Guru mempersiapkan diri dengan antusias & 10 & $76,9 \%$ \\
\hline $\mathbf{2}$ & Guru aktif bertanya tentang hal yang tidak diketahui & 9 & $69,2 \%$ \\
\hline $\mathbf{3}$ & Guru memanfaatkan forum diskusi & 12 & $92,3 \%$ \\
\hline $\mathbf{4}$ & Guru dapat menyebutkan beberapa metode yang sering dilakukan & 9 & $69,2 \%$ \\
\hline $\mathbf{5}$ & Guru menyimak penjelasan fasilitator dengan antusias & 10 & $76,9 \%$ \\
\hline $\mathbf{6}$ & $\begin{array}{l}\text { Guru dapat mempraktikkan metode yang dikuasai dalam praktik } \\
\text { singkat }\end{array}$ & 5 & $38,5 \%$ \\
\hline $\mathbf{7}$ & $\begin{array}{l}\text { Guru disiplin memasuki ruangan sesuai dengan waktu yang } \\
\text { ditentukan }\end{array}$ & 9 & $69,2 \%$ \\
\hline
\end{tabular}

Pada tabel 3, dapat dilihat bahwa dari semua guru yang ikut ada beberapa yang berbeda dalam mengikuti MGMP selama dua kali pertemuan, pada item pertama guru mempersipakan diri dengan antusias yaitu guru mempersipkan laptop, perangkat pembelajaran dan kesiapan lainnya, dari hasil pengamatan ada 10 orang atau $76,9 \%$ yang melakukannya. Pada item ke-2, ada 9 orang atau 69,2\% yang aktif dalam forum diskusi, meskipun tampak bahwa pada item ke-3 guru memanfaatkan forum diskusi untuk bertukar pikiran, dalam hal ini hampir semua guru melakukannya yaitu 12 orang atau $92,3 \%$. Sementara pada item ke-4 pada dua hari pelaksanaan, baru 9 orang atau $69,2 \%$ yang mampu memperlihatkan menyebutkan metode, model, dan filosofinya. Pada item ke-5, guru antusias menyimak penjelasan fasilitator, dapat diamati ada 10 orang atau $76,9 \%$ selebihnya belum terlihat menyimak fasilitator. Dalam mempraktikkan metode yang dikuasai ada 5 atau $38 \%$ guru yang tampak menguasai dengan baik metode yang dipraktikkan. Sementara kedisiplinan memeasuki ruangan untuk tiap pertemuan tercatat 9 orang atau $69,2 \%$ guru tidak pernah terlambat.

d. Refleksi

Pada dasarnya refleksi dilakukan untuk melihat kelemahan yang terdapat pada siklus pertama, untuk dilakukan perbaikan pada siklus berikutnya. Pada pelaksanaan MGMP tahap pertama yang juga dijadikan siklus I oleh peneliti, maka ada beberapa refleksi yaitu:

a. Guru belum mampu menunjukkan kedisiplinan dalam mengikuti pertemuan.

b. Guru belum menunjukkan perhatian penuh pada materi tertentu

c. Guru belum memperlihatkan persiapan yang maksimal, ada yang tidak membawa perangkat pembelajaran, dan laptop.

Dari tiga masalah yang yang direfleksi pada pertemuan siklus pertama di atas, maka peneliti akan melanjutkan pada siklus II, dengan perbaikan-perbaikan sebagai berikut:

a. Peneliti meminta guru melakukan cek list perangkat pembelajaran serta laptop sebelum memasuki ruangan, dan diumumkan sebelumnya.

b. Penelitia meminta fasilitator untuk merubah bentuk forum dan dibentuk kelompokkelompok praktik.

c. Peneliti membuat instrumen penilaian untuk postes.

d. Peneliti membuat instrumen berupa angket untuk melihat kemajuan guru yang mengikuti MGMP

\section{Siklus II}

Dengan perbaikan sebagai hasil refleksi dari siklus pertama maka peneliti melanjutkan pada siklus II dengan langkah langkah sebagai berikut: 
a. Perencanaan

Pada perencanaan siklus II, peneliti mengadakan kegiatan sebagai berikut:

1) Menyiapkan instrumen, soal dan kisi-kisi

2) Menyiapkan pedoman observasi

3) Menyiapkan angket

4) Mendiskusikan hasil siklus II dengan pengawas

b. Pelaksanaan

Pada tahap pelaksanaan akan dibagi menjadi dua kali pertemuan untuk siklus II, dengan kegiatan sebagai berikut:
1) Pertemuan dimulai tanggal 22 September 2018 dan 29 September 2018 dengan integrasi pendidikan karakter bangsa, dan materi PKG dan PKB.

2) Observasi dilakukan secara langsung oleh peneliti dengan pedoman observasi yang telah dibuat sebelumnya.

c. Observasi

Hasil pengamatan untuk pertemuan pertama pada siklus II dapat dilihat pada tabulasi berikut ini:

Tabel 4. Hasil observasi pertemuan I dan II siklus II

\begin{tabular}{clcc}
\hline No & \multicolumn{1}{c}{ Item pengamatan } & Jumlah & Persentase \\
\hline 1 & Guru mempersiapkan diri dengan antusias & 13 & $100 \%$ \\
\hline 2 & Guru aktif bertanya tentang hal yang tidak diketahui & 12 & $92,3 \%$ \\
\hline 3 & Guru memanfaatkan forum diskusi & 13 & $100 \%$ \\
\hline 4 & Guru dapat membuat pembuatan soal-soal berbasis HOTS & 13 & $100 \%$ \\
\hline 5 & Guru menyimak penjelasan fasilitator dengan antusias & 13 & $100 \%$ \\
\hline 6 & Guru dapat mempraktikkan contoh penilaian dalam PKG & 10 & $76,9 \%$ \\
\hline 7 & $\begin{array}{l}\text { Guru disiplin memasuki ruangan sesuai dengan waktu yang } \\
\text { ditentukan }\end{array}$ & 13 & $100 \%$ \\
\hline 8 & Guru mengerjakan tes dengan baik & 13 & $100 \%$ \\
\hline
\end{tabular}

Pada tabel 4, dapat dilihat bagaimana semua guru sudah memperlihatkan kesiapan yang maksimal yaitu 13 orang atau $100 \%$ guru sudah mempersiapkan diri. Pada item ke-2, bagaimana 12 orang atau $92.3 \%$ guru aktif bertanya, dan semua guru sudah memanfaatkan forum diskusi, diskusi menjadi "hangat" dan bersemangat, begitu juga halnya dengan guru menyimak penjelasan fasilitator semua guru 13 orang atau $100 \%$ antusias dengan penjelasan fasilitator, disamping itu materi ini juga masih baru dan berhubungan langsung dengan profesi guru. Pada item ke-7 ketika guru mempraktikkan penilaian PKG masih ada permasalah pada dua orang guru yang belum memahami bentuk penilaian dalm PKG sehingga hanya 10 atau $76 \%$ yang dapat melakukannya. Untuk tes akhir dan pengisian angket guru guru melakukan dengan tertib.

d. Hasil Penilaian Postes

Setelah empat kali pertemua untuk dua siklus maka peneliti mengadakan postes untuk mengetahui kemampuan guru dalam memahami materi-materi yang di MGMP-kan selama ini.
Adapun kisi-kisi soal postes sama dengan kisi-kisi pretes yaitu:

a. Penguasaan metode-metode pembelajaran

b. Penguasaan filsafat pendidikan

c. Penguasaan pendidikan karakter bangsa

d. Penguasaan materi PKG dan PKB

Tabel 5. Hasil postes

\begin{tabular}{clcc}
\hline No. & Kualifikasi & $\begin{array}{c}\text { Jumlah } \\
\text { guru }\end{array}$ & $\begin{array}{c}\text { Persentase } \\
(\boldsymbol{\%})\end{array}$ \\
\hline 1. & Sangat Baik & 4 & $30,8 \%$ \\
\hline 2. & Baik & 8 & $61,5 \%$ \\
\hline 3. & Cukup & 1 & $7,7 \%$ \\
\hline 4. & Kurang & 0 & 0 \\
\hline & JUMLAH & 13 & 100 \\
\hline
\end{tabular}

Pada tabel 5. dapat dilihat bahwa guru yang berada pada hasil tes (postes) sangat baik 4 orang atau $30,8 \%$, dengan kualifikasi baik 8 orang atau $61,5 \%$, kualifikasi cukup 1 orang atau $7,7 \%$, dan tidak ada yang berkualifikasi kurang. Perbedaan data untuk pretes dan postes tersebut dapat dilihat pada grafik berikut: 
JIKAP PGSD: Jurnal Ilmiah Ilmu Kependidikan

Grafik 1. Perbandingan hasil pretes dan postes dalam persentase

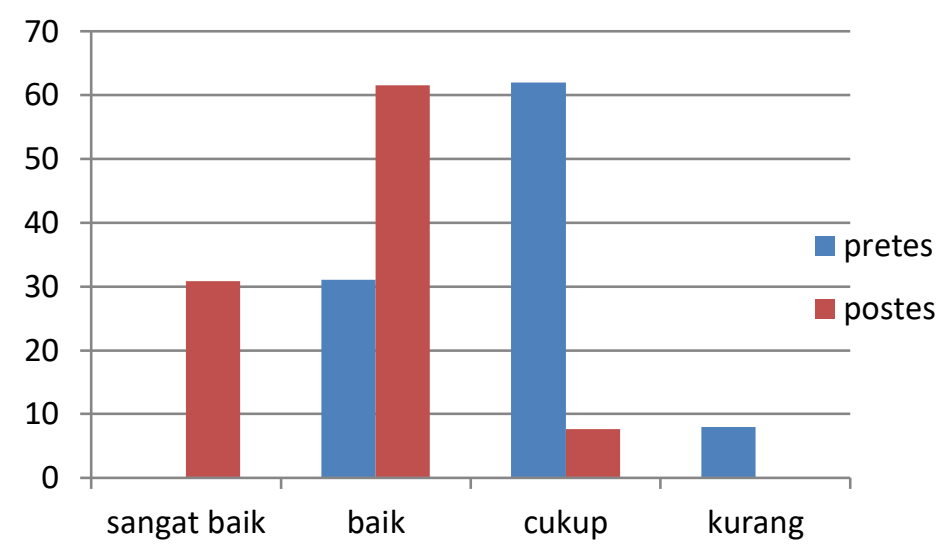

Hasil angket guru dengan dengan menggunakan skala Guttman yaitu angket dengan jawaban tegas "ya" dan "tidak". Pada

skala ini maka tiap option akan diberikan nilai yaitu jawaban "ya" $=2$, dan jawaban "tidak" $=1$.

Tabel 6. Hasil perhitungan data angket guru

\begin{tabular}{|c|c|c|c|c|c|c|c|c|c|c|c|}
\hline \multirow[t]{2}{*}{ No } & \multicolumn{10}{|c|}{ Jawaban responden untuk item nomor: } & \multirow[t]{2}{*}{ Jml } \\
\hline & 1 & 2 & 3 & 4 & 5 & 6 & 7 & 8 & 9 & 10 & \\
\hline 1 & 2 & 2 & 1 & 2 & 1 & 1 & 2 & 2 & 2 & 2 & 17 \\
\hline 2 & 2 & 2 & 2 & 2 & 2 & 1 & 1 & 2 & 2 & 2 & 18 \\
\hline 3 & 2 & 2 & 1 & 2 & 2 & 1 & 1 & 2 & 2 & 1 & 16 \\
\hline 4 & 2 & 2 & 1 & 2 & 1 & 1 & 2 & 2 & 2 & 1 & 16 \\
\hline 5 & 2 & 2 & 1 & 2 & 1 & 2 & 2 & 2 & 2 & 2 & 18 \\
\hline 6 & 2 & 2 & 1 & 2 & 1 & 1 & 2 & 2 & 1 & 1 & 15 \\
\hline 7 & 2 & 2 & 2 & 2 & 2 & 2 & 2 & 2 & 2 & 1 & 19 \\
\hline 8 & 2 & 2 & 2 & 2 & 2 & 1 & 1 & 2 & 2 & 2 & 18 \\
\hline 9 & 2 & 2 & 2 & 2 & 2 & 2 & 1 & 2 & 1 & 1 & 17 \\
\hline 10 & 2 & 2 & 1 & 2 & 1 & 2 & 2 & 2 & 2 & 1 & 17 \\
\hline 11 & 2 & 2 & 1 & 2 & 1 & 1 & 1 & 2 & 2 & 2 & 16 \\
\hline 12 & 2 & 2 & 2 & 2 & 1 & 1 & 2 & 2 & 2 & 2 & 18 \\
\hline 13 & 2 & 2 & 2 & 2 & 1 & 1 & 2 & 2 & 1 & 2 & 17 \\
\hline \multicolumn{11}{|c|}{ Jumlah } & 222 \\
\hline
\end{tabular}

Untuk diketahu bahwa jumlah skor kriterium (bila setiap skor mendapat nilai tertinggi) $=2 \times 10 \times 13=260$ untuk ini skor tertinggi $=2$, jumlah butir $=10$, dan jumlah responden $=13$. Jumlah hasill pengumpulan data $=222$. Dengan demikian peningkatan kemampuan guru melalui MGMP sekolah dalam persepsi 13 orang guru adalah 222/260x100= $85 \%$, angka ini menujukkan bahwa dalam persepsi guru MGMP sekolah sangat bermanfaat untuk meningkatkan kemampuan mereka dalam pembentukan profesionalisme.

Kualitas guru sangat menentukan bentuk-bentuk kompetensi yang di lakoni seorang guru dalam kehidupannya. Guru dalam undang-undang sudah menempati posisi yang memadai dengan lahirnya UU No 14 tahun 2005 tentang Guru dan Dosen. Juga dalam peraturan pemerintah No. 74 tahun 2008 adalah pendidik profesional dengan tugas utama mendidik, mengajar, membimbing, mengarahkan, melatih, menilai, dan mengevaluasi peserta didik pada pendidikan anak usia dini jalur pendidikan formal, pendidikan dasar, dan pendidikan menengah.

Pada dasarnya kualitas guru ditentukan oleh kematangan dan kemampuan profesionalisme guru seperti yang dicantumkan dalam undang-undang. Dengan demikian, untuk menjadi guru profesional bukan hanya ditentukan oleh satu kompetensi, akan tetapi seluruh kompetensi harus memberikan peran yang sama, sehingga tercipta guru paripurna dan berkualitas. 
Halnya dengan kondisi di Madrasah Aliyah Negeri 1 Barru, keseluruhan guru berjumlah 42 orang dari berbagai latar ilmu. Secara input guru terdiri dari guru PNS dan honorer sehingga untuk mempertahankan kualitas guru, maka sekolah berinisiatif mengadakan MGMP sekolah dan dimasukkan dalam anggaran 2018/2019.

Pada penelitian ini pengembangan keilmuan dalam MGMP dapat dirasakan secara nyata oleh guru yang menerima manfaat langsung dari pelaksanaan MGMP sekolah, hal ini dapat dilihat pada hasil observasi dan angket yang disebarkan pada seluruh responden. Manfaat dalam ber-MGMP memang sangat banyak sesuai dengan apa yang pernah diuraikan bahwa salah satu manfaat MGMP adalah mengakses pengetahuan secara bersama, sehingga guru-guru di dalam MGMP akan menemukan masalah yang sama dan memberikan pemecahan masalah yang sesuai.

Pada penelitian tindakan sekolah kali ini, dapat dilihat peningkatan kemampuan guru secara signifikan, bahwa guru terlihat antusias dan berusaha memanfaatkan MGMP sekolah sebagai wadah pengembangan diri untuk peningkatan kualitas guru.

Bahkan dari hasil angket yang dibagikan terlihat guru memiliki persepsi yang sangat baik dengan angka $85 \%$ dalam melihat manfaat MGMP sekolah dalam meningkatkan kemampuan mereka.

\section{SIMPULAN SARAN}

Berdasarkan hasil penelitian mengenai peningkatan kemampuan guru melalui pemberdayaan MGMP sekolah di Madrasah Aliyah Negeri 1 Barru Kabupaten Barru, diperoleh simpulan bahwa terjadi peningkatan kemampuan guru melalui pemberdayaan MGMP sekolah di Madrasah Aliyah Negeri 1 Barru Kabupaten Barru.

Berdasarkan kesimpulan yang diperoleh dari penelitian tindakan sekolah ini, penulis merekomendasikan:

1. Kepada guru peserta MGMP sekolah:

a. Memanfaatkan kegiatan MGMP sekolah sebagai wadah pemberdayaan untuk meng "Up date" kemampuan profesionalnya

b. Memanfaatkan MGMP sekolah untuk menjalin silaturahim dan pengembangan ilmu pengetahuan.

2. Kepada pengawas tingkat SLTP/SLTA Dinas Pendidikan, agar mengupayakan semua sekolah dalam koordinasinya memaksimalkan peran MGMP sekolah untuk mengembangkan kualitas dan kemampuan guru mata pelajaran.

\section{DAFTAR RUJUKAN}

Dadi Permadi dan Daeng Arifin. 2007. Kepemimpinan Transpormasional Kepala Sekolah dan Komite Sekolah. Bandung: PT Sarana Panca Karya.

Depdiknas. 2008. Pedoman Penelitian Tindakan Sekolah (School Action Research) Peningkatan Kompetensi Supervisi Pengawas Sekolah SMA/SMK. Jakarta: Dirjen PMPTK.

Ibrahim Bafadal. 2006. Peningkatan Profesionalisme Guru Sekolah Dasar. Jakarta: Bumi Aksara,.

Mantja, W. 2008. Manajemen Pendidikan dan Supervisi Pengajaran. Malang: Elang Mas.

Sudjana, H. Nana. 2009. Penelitian Tindakan Kepengawasan, Konsep dan Aplikasinya bagi Pengawas Sekolah. Jakarta: Binamitra Publishing.

Sukmadinata, Nana Syaodih. 2006. Metode Penelitian Pendidikan. Jakarta: PT. Remaja Rosdakarya.

Wahjo, Sumidjo. 2002. Kepemimpinan Kepala Sekolah, Tinjauan Teoritik dan Permasalahannya. Jakarta: PT Raja Grafindo Persada. 